\title{
Using Quizizz to Integrate Fun Multiplayer Activity in the Accounting Classroom
}

\author{
Fang Zhao ${ }^{1}$ \\ ${ }^{1}$ Girard School of Business, Merrimack College, North Andover MA, USA \\ Correspondence: Fang Zhao, Girard School of Business, Merrimack College, North Andover MA, 01845 USA. \\ E-mail: zhaof@merrimack.edu \\ Received: September 8, 2018 \\ Accepted: January 14, 2019 \\ Online Published: January 15, 2019 \\ doi:10.5430/ijhe.v8n1p37 \\ URL: https://doi.org/10.5430/ijhe.v8n1p37
}

\begin{abstract}
This study investigates the effectiveness of Quizizz on enhancing students' learning experiences in an accounting classroom. Quizizz is an educational app that enables students to participate in fun multiplayer class activities. After doing in-class exercises using Quizizz, students report that this app brings positive impact on their learning experiences. Class section in which Quizizz is applied more frequently reports higher scores on the satisfaction of using this app and higher scores on the instructor's teaching evaluation.
\end{abstract}

Keywords: educational app, Quizizz, gamification, accounting classroom, engagement

\section{Introduction}

Educational apps have been used extensively in higher education in recent years, such as Socrative, Kahoot, iClicker. These apps enable students to participate in interactive class activities using their mobile devices to improve learning experiences. While introducing technology to classroom is the trend in higher education, accounting faculty are resistant to adopt new technologies in their teaching practice (Watty, McKay \& Ngo, 2016), thus the application of technology in accounting classrooms is not very prevalent.

This study examines students' perception of using Quizizz, an educational app, in an introductory accounting classroom. The introductory accounting class is the first accounting class taken by all business majors and non-business majors who minor in business. Students usually lack motivation to actively participate in the learning activities. Young students often seek to have some fun learning experiences in class, but accounting is a subject which is perceived by students as not having much "fun".

Quizizz is a game-based educational app, which brings multiplayer activities to classrooms and makes in-class exercises interactive and fun. Using Quizizz, students can do in-class exercises on their electronic devices. Unlike other educational apps, Quizizz has game characteristics like avatars, themes, memes and music, which are entertaining in the learning process. Quizizz also allows students to compete with each other and motivates them to study. Students take the quiz at the same time in class and see their live ranking on the leaderboard. Instructors can monitor the process and download the report when the quiz is finished to evaluate students' performance. Using this app in the accounting classroom helps stimulate students' interest and improve students' engagement.

Although there are some previous studies describing the application of Quizizz and examining students' perception of using Quizizz, there is no study examining the application of Quizizz in the accounting classroom. This study investigates students' feedback of using Quizizz in an accounting classroom. Besides, this study examines the effect of Quizziz's application frequency on students' feedback and instructors' teaching evaluations.

For two consecutive semesters, Quizizz was applied for in-class exercises in an introductory accounting class. Students used their mobile devices to answer questions and received immediate feedback. At the end of each semester, students' feedback of using Quizizz was collected using surveys.

This study finds that students perceive that using Quizizz enhances their learning. They report that: Quizizz is easy to use; doing in-class exercises using Quizizz is better than doing in-class exercises on paper; using Quizizz reduces their test anxiety; they would like to use Quizizz in future classes. This study also finds that class section in which Quizizz is applied more frequently reports not only higher scores on the satisfaction with this app, but also higher scores on the teaching evaluation for the instructor. 
The next section provides a brief review of prior studies. Section 3 describes the characteristics of Quizizz and how to apply it for in-class exercises. Section 4 describes the research design. Section 5 summarizes the results. Section 6 concludes this study.

\section{Prior Studies}

Gamification enables learners to change the ways of thinking through following the gaming rules in the problem-solving process (Zicherman \& Cunningham, 2011). Gamification is helpful in overcoming the difficulties in learning and motivating participation in the learning activities (Codish \& Ravid, 2014; Bruder, 2014). Using blended learning methods and techniques, gamification has played an important role in a successful learning process in today's world (Çeker \& Özdaml1, 2017).

Quizizz is an educational app that applies the concept of gamification (MacNamara \& Murphy, 2017). The colorful interface, avatars and music provide students a similar experience as a game does. After students answer each question, Quizizz will show pictures with memes to tell whether the answer is right or wrong. This is a treat to students (Miller, 2017).

Prior studies describe different ways of applying Quizizz. Quizizz can be used to organize classroom activities and prepare tests (Dean, 2017; MacNamara \& Murphy, 2017). Quzizz can also be used in flipped class lectures (Porcaro, Jackson, McLaughlin, \& O'Malley, 2016; Dayal, Green, \& Browne, 2016). Boulden, Hurt, and Richardson (2017) use Quizizz and other educational apps to help students recognize the difference between productive and nonproductive questions. Suo, Suo, and Zalika (2018) apply Quizizz in the Arabic classroom and find that it is effective to enhance students' learning as a game-based learning tool. Quizizz is also applied in Physics course enrolled by engineering students and is found to be effective in increasing learning outcomes and decreasing anxiety (Aşıksoy \& Sorakin, 2018). Hamilton-Hankins (2017) introduce Quizizz in an English Language Arts Classroom and find it has positive impact on student engagement. Chaiyo and Nokham (2017) find differences in students' perception of using different educational apps. Students respond more positively when using Kahoot and Quizizz than using Google forms. Boulden et al. (2017) find that students are more focused and attentive to the quiz when using Quizizz. The response rate of in-class exercises using Quizizz is higher than that using Kahoot.

To my knowledge, there is no study examining the application of Quizizz in accounting classes.

\section{Characteristics and Application of Quizizz}

Design and start a quiz (game): Quizzes can be designed in different formats like true or false, multiple choices, etc. Instructors can choose to set the quizzes as public or private. If the quizzes are public, they can be shared with other instructors. In class, instructors can start a quiz by sharing a game code (generated by the website automatically) to students, students can enter the game code and join the game easily on their mobile devices. Each student will see a unique avatar assigned to him/her when joining the game. They usually start to get excited at that time. Instructors can monitor students' joining the game (with their names and avatars shown on the screen) and start the game when all the students have joined.

Instructors can customize the game in several ways, such as turning on (off) the background music; ranking based on correction rate only or both correction rate and time used for completing the quiz; ranking showing all the students or only the top five students; shuffle questions or not, etc. Besides using it for in-class exercises, instructors can also set the quizzes as homework so that students can work on the questions on their mobile devices after class.

Doing a quiz (game): After answering each question, there is immediate feedback in the form of a meme shown on the screen. Funny pictures pop up with sentences like "good job" if the answer is correct or "try again" if the answer is wrong. Students are amused by the memes and feel relaxed and motivated to answer the next question. One of the special characteristics about Quizizz is the leaderboard, which shows the live ranking of students based on their performance. Students can see their live ranking throughout the quiz.

Finishing a quiz (game): instructors can end the game when all the students finish the quiz. Students can review all the questions (with both their own answers and solutions) and ask questions. Instructors can easily highlight important questions based on the correction rate and help students figure out where they need to improve. The quiz reports are available on the website and can be downloaded as Excel files.

Google Classroom Integration: Quizizz can be integrated with Google Classroom. This integration facilitates assignment tracking and enhances student safety since they are authenticated using their school Google accounts (Medvedovska, Skarlupina, \& Turchyna, 2016). 


\section{Research Design}

Quizizz was applied for two consecutive semesters in the same introductory accounting course (taught by the same instructor) in which different students were enrolled. In the first semester (Fall 2017), it was applied to two sections of introductory accounting class (Accounting for Business) taught by the same instructor. One section used Quizizz more frequently throughout the semester. The other section used Quizizz only at the end of the semester. The purpose of having two sections both using Quizizz is to investigate whether the frequency of applying this app affects students' satisfaction with this app. In the second semester (Spring 2018), Quizizz was applied in one large section of the same course.

Table 1. Class Sections Information

\begin{tabular}{|c|c|c|c|}
\hline Semester & Section & $\begin{array}{l}\text { Number } \\
\text { Participants }\end{array}$ & Frequency of Using Quizizz \\
\hline \multirow[t]{2}{*}{ Fall 2017} & Section 1 & 29 & high \\
\hline & Section 2 & 39 & low \\
\hline Spring 2018 & Section 3 & 62 & high \\
\hline
\end{tabular}

Table 1 summarizes the information on the class sections in which Quizizz was applied for this study. Surveys using 5 -point Likert scale were conducted at the end of the semesters (5 strongly agree, 4 agree, 3 neutral, 2 disagree, 1 strongly disagree).

\section{Results}

Table 2. Quizizz Survey Results

\begin{tabular}{|c|c|c|c|}
\hline \multirow[b]{3}{*}{ Survey Questions } & \multicolumn{2}{|l|}{ Fall 2017} & \multirow{2}{*}{$\begin{array}{l}\text { Spring } 2018 \\
\text { Section } 3\end{array}$} \\
\hline & Section 1 & Section 2 & \\
\hline & Mean & Mean & Mean \\
\hline 1. Quizizz is easy to use & 5.00 & 4.92 & 4.77 \\
\hline $\begin{array}{l}\text { 2. Using Quizizz doing in-class exercises helps me review the course } \\
\text { materials. }\end{array}$ & 4.76 & 4.77 & 4.68 \\
\hline $\begin{array}{l}\text { 3. Using Quizizz is effective in enhancing my engagement in the } \\
\text { classroom. }\end{array}$ & 4.72 & 4.76 & 4.56 \\
\hline $\begin{array}{l}\text { 4. Using Quizizz doing in-class exercises stimulates my interest in } \\
\text { learning accounting. }\end{array}$ & 4.79 & 4.55 & 4.39 \\
\hline 5. Using Quizizz doing in-class exercises is fun. & 4.79 & 4.67 & 4.39 \\
\hline $\begin{array}{l}\text { 6. The ranking function (leaderboard) in Quizizz motivates me to } \\
\text { study. }\end{array}$ & 4.55 & 4.31 & 3.90 \\
\hline 7. Using Quizizz helps me concentrate in class. & 4.69 & 4.33 & 4.28 \\
\hline 8.Using Quizizz doing in-class exercises reduces my test anxiety. & 4.32 & 4.23 & 3.97 \\
\hline $\begin{array}{l}\text { 9. Doing in-class exercises using Quizizz is more helpful in my } \\
\text { learning than doing in-class exercises on paper. }\end{array}$ & 4.62 & 4.59 & 4.13 \\
\hline $\begin{array}{l}\text { 10. Doing in-class exercises using Quizizz helps me know my } \\
\text { classmates. }\end{array}$ & 4.31 & 3.62 & 3.32 \\
\hline $\begin{array}{l}\text { 11. Doing in-class exercises using Quizizz reduces distraction } \\
\text { caused by cell phone or other electronic devices. }\end{array}$ & 4.45 & 4.08 & 4.15 \\
\hline 12. I would like to use Quizizz more in the future. & 4.83 & 4.62 & 4.34 \\
\hline
\end{tabular}

Table 2 shows the survey results for all the sections. Overall the results show that students perceive that Quizizz enhances their learning. They agree that this educational app is easy to use (mean scores 5.00, 4.92, 4.77 for the three sections respectively). They agree that Quizizz is helpful in enhancing their engagement in the classroom (mean scores 4.72, 4.76, 4.56), stimulating their interest in learning accounting (mean scores 4.79, 4.55, 4.39), reducing test 
anxiety (mean scores 4.32, 4.23, 3.97), helping them know their classmates (mean scores 4.31, 3.62, 3.32). They agree that doing in-class exercises using Quizizz is more helpful in their learning than doing in-class exercises on paper (mean scores 4.62, 4.59, 4.13).

Table 3. Individual Feedback from Students

Quizizz was fun to use and helped me learn from my mistakes.

I like how it is competitive and can be used as a study tool for the test.

I like that it allows the class as a whole to participate and track our progress. competition always forces students to work harder so that they can win and Quizziz does that.

I liked that it kept me focused.

I love the features: the music, the colors, the questions.

I like how there is a ranking factor. I like that it gives you the results right after you answer it. It is fun and easy to use.

I like Quizizz because it changes things up in class, and makes it more fun to learn the material.

I like Quizizz because it is easy to use, helpful in making me remember material, fun to use too. I like that you can review your correct/incorrect answers afterwards. Keeps me concentrated. I don't dislike anything about Quizizz.

I like how it is easy to use and motivates me to study harder for the next quiz to be on the top leaderboard.

I like that it makes you want to be competitive and be at the top of the leaderboard.

I liked the live leaderboard because I could see who was better than me and I needed to be better than those people when the next Quizizz came around.

I enjoy Quizizz because I can go back at a later date and review the answers to help me prepare for exams. It is more fun than just writing on paper, and I can interact with classmates.

I love how its interactive, the memes, and the music.

I liked the competitiveness of the game, and it also showed me what I needed to work on in particular.

Table 3 reports the individual feedback from the students. The results show that they like Quizizz because it is fun, interactive and keeps them focused. They particularly like the leaderboard feature which makes them competitive and motivates them to perform better.

Different from previous studies, this study also examines the effect of the frequency of applying Quizizz on students' feedback. Students' satisfaction of using an educational app may increase when they use it more because of the familiarity, but the satisfaction may also decrease because of the boredness and repetition. In the same semester (Fall 2017), Quizizz was applied in two sections of the same accounting course with different frequency. Students in section 1 used Quizizz more frequently (most class meetings) while students in section 2 used Quizizz only at the end of the semester. 
Table 4. Comparative Students' Feedback

\begin{tabular}{|c|c|c|c|c|c|c|c|}
\hline \multirow[b]{2}{*}{ Questions } & \multicolumn{3}{|c|}{$\begin{array}{l}\text { Section } 1 \\
\text { (use more frequently) }\end{array}$} & \multicolumn{3}{|c|}{$\begin{array}{l}\text { Section } 2 \\
\text { (use less frequently) }\end{array}$} & \multirow[t]{2}{*}{$\begin{array}{l}\mathrm{t} \\
\text { statistics }\end{array}$} \\
\hline & Mean & Median & $\begin{array}{l}\text { Standard } \\
\text { Deviation }\end{array}$ & Mean & Median & $\begin{array}{l}\text { Standard } \\
\text { Deviation }\end{array}$ & \\
\hline Quizizz is easy to use & 5.00 & 5 & 0.00 & 4.92 & 5 & 0.27 & 1.780 \\
\hline $\begin{array}{l}\text { Using Quizizz doing in-class } \\
\text { exercises stimulates my interest } \\
\text { in learning accounting. }\end{array}$ & 4.79 & 5 & 0.41 & 4.55 & 5 & 0.76 & 1.672 \\
\hline $\begin{array}{l}\text { The ranking function } \\
\text { (leaderboard) in Quizizz } \\
\text { motivates me to study. }\end{array}$ & 4.55 & 5 & 0.78 & 4.31 & 5 & 1.00 & 1.126 \\
\hline $\begin{array}{l}\text { Using Quizizz helps me } \\
\text { concentrate in class. }\end{array}$ & 4.69 & 5 & 0.54 & 4.33 & 5 & 0.77 & 2.236 \\
\hline $\begin{array}{l}\text { Doing in-class exercises using } \\
\text { Quizizz helps me know my } \\
\text { classmates. }\end{array}$ & 4.31 & 5 & 0.97 & 3.62 & 4 & 1.23 & 2.580 \\
\hline $\begin{array}{l}\text { Doing in-class exercises using } \\
\text { Quizizz reduces distraction } \\
\text { caused by cell phone or other } \\
\text { electronic devices. }\end{array}$ & 4.45 & 5 & 0.87 & 4.08 & 4 & 1.11 & 1.547 \\
\hline $\begin{array}{l}\text { I would like to use Quizizz } \\
\text { more in the future. }\end{array}$ & 4.83 & 5 & 0.47 & 4.62 & 5 & 0.63 & 1.589 \\
\hline
\end{tabular}

Table 4 shows the comparative survey results of the two sections which have different frequency of using Quizizz. Although both sections report positive feedback and most questions have similar responses (not tabulated), there are significant differences in certain items. Section 1 report higher score (5.00) in the "easy to use" question than Section 2 (4.92). Students who use Quizizz more frequently are more familiar with this app, thus they are more agreeable that it is easier to. Section 1 report higher score (4.69) in the question regarding "help me concentrate in class" than section 2 (4.33). This may be caused by that more familiarity of this app causes less distraction by adapting to new technology. The biggest difference in the feedback between the two sections is the perception about "Doing in-class exercises using Quizizz helps me know my classmates". Section 1 report much higher score (4.31) than section 2 (3.62). This is likely to be caused by the "leaderboard" function in Quizizz, which displays all the students' names and ranking in each of the in-class exercises. Students using Quizizz more have seen their peers' names more frequently on learderboard. In class, they are usually curious to know the higher ranked peers and even compliment them on their good performance. Therefore, they are more agreeable that Quizizz help them know their classmates than those students in another section who use Quizizz less frequently and see leaderboard fewer times.

Table 5. Comparative Teaching Evaluations

\begin{tabular}{l|l|l|l}
\hline \multirow{2}{*}{ Questions } & $\begin{array}{l}\text { Section 1 } \\
\text { (use more } \\
\text { frequently) }\end{array}$ & $\begin{array}{l}\text { Section 2 } \\
\text { (use less } \\
\text { frequently) }\end{array}$ & difference \\
\cline { 2 - 4 } & Mean & Mean & 0.80 \\
\hline $\begin{array}{l}\text { Did the instructor use examples, audio visual, and/or personal } \\
\text { experience to clarify explanations? }\end{array}$ & 3.60 & 2.80 & 0.56 \\
\hline Was the material enthusiastically presented in class? & 3.36 & 2.80 & 0.25 \\
\hline Did the instructor stress important material? & 3.48 & 3.23 & \\
\hline
\end{tabular}

Table 5 highlights the differences in the teaching evaluations of the two sections in which Quizizz is applied with different frequency. T test cannot be calculated since only the overall evaluation scores are provided to the instructor. Since the teaching evaluation is conducted by the university, the scale is different compared to that in the previous 
tables. For each question, students can choose the options A, B, C, D or E (from excellent to poor). A: 4 points; B: 3 points; C: 2 points; D: 1 point; E: 0 point. Thus, the maximum score is 4 points for each question in the teaching evaluation.

Although both sections are taught by the same instructor, there are some differences in the evaluation scores. This table reports selected questions that have bigger differences in evaluation scores. For the question "Did the instructor use examples, audio visual, and/or personal experience to clarify explanations?", Section 1 reports 3.60 while section 2 reports 2.80. It may be caused by that more frequent application of Quizizz is perceived by students as more visual examples. Section 1 reports higher score (3.36) in the question "Was the material enthusiastically presented in class?" than section 2 (2.80). It is likely that the colorful and vivid visualization in Quizizz may enhance students' perception of professor's enthusiasm. Section 2 reports higher score (3.48) in the question "Did the instructor stress important material?" than section 2 (3.23). This is possibly because answering questions using Quizizz deepens students' impression of the important materials related to the questions.

\section{Conclusion}

This study examines students' feedback of using Quizizz in an accounting classroom and finds that this educational app enhances students' learning experiences. Students agree that Quizizz is easy to use; using Quizizz doing in-class exercise is fun, helps them review the course materials and stimulates their interest in learning accounting. They like the features of this app, especially the leaderboard, which shows the live ranking of their performance and motivates them to study. They agree that Quizizz helps them concentrate in class and reduces their test anxiety. They prefer doing in-class exercises using Quizizz than on paper.

This study also compares students' feedback of two class sections in which Quizizz is used differently in term of frequency. Students who use Quizizz more frequently agree more strongly that Quizizz is easy to use, stimulates their interest, helps them concentrate in class, and reduces distraction caused by electronic devices.

Furthermore, students who use Quizizz more frequently in the semester give higher evaluation scores to the instructor, especially for the items about visual examples, enthusiasm, and stressing important materials.

Overall, this study finds that Quizizz is perceived as having positive impact on students' engagement and learning outcomes in an accounting classroom. Generally, students' feedback is consistent in different semesters and in different class sizes.

\section{Acknowledgements}

The author thanks the workshop participants at the 2017 American Accounting Association Teaching, Learning and Curriculum Section Midyear Colloquium for their helpful comments. The author thanks Merrimack College Institutional Review Board (IRB) for approving this study. The author thanks Merrimack College Girard School of Business for providing the research funding.

\section{References}

Aşıksoy, G., \& Sorakin, Y. (2018). The effects of clicker-aided flipped classroom model on learning achievement, Physics anxiety and students' perceptions. International Online Journal of Education and Teaching (IOJET), 5(2), 334- 346. http://iojet.org/index.php/IOJET/article/view/389/238

Boulden, D. C., Hurt, J. W., \& Richardson, M. K. (2017). Implementing digital tools to support student questioning abilities: A Collaborative Action Research Report. i.e.: inquiry in education, 9(1). Retrieved from https://files.eric.ed.gov/fulltext/EJ1171738.pdf

Bruder, P. (2014). Gamification in the classroom. Retrieved from https://www.njea.org/gamification-in-the-classroom/

Çeker, E., \& Özdaml1, F. (2017). What 'Gamification" is and what it's not. European Journal of Contemporary Education, 6(2), 221-228. https://files.eric.ed.gov/fulltext/EJ1146137.pdf

Chaiyo, Y., \& Nokham, R. (2017). The effect of Kahoot, Quizizz and Google Forms on the student's perception in the classrooms response system. International Conference on Digital Arts, Media and Technology (ICDAMT), 178-182. https://doi.org/10.1109/ICDAMT.2017.7904957

Codish, D., \& Ravid, G. (2014). Personality based gamification - educational gamification for extroverts and introverts. the 9th Chais Conference for the Study of Innovation and Learning Technologies: Learning in the Technological Era, Israel. https://www.openu.ac.il/innovation/chais2014/download/E2-2.pdf 
Dayal, M., Green, H., \& Browne C. (2016). Flipping human anatomy lectures: Engaging students using digital media and mini lectures. https://www.adelaide.edu.au/flipped-classroom/resources/11_Anatomy.pdf

Dean, H. (2017). Creating critical readers: connecting close reading and technology. The California Reader. 50(4), 8-11.

Hamilton-Hankins, O. J. (2017). The impact of technology integration on the engagement levels of ten second grade students in an English Language Arts classroom. University of South Carolina Scholar Commons. https://scholarcommons.sc.edu/cgi/viewcontent.cgi?article=5360\&context=etd

MacNamara, D., \& Murphy, L. (2017). Online versus offline perspectives on gamified learning. GamiFIN Conference, University Consortium of Pori, Finland. http://ceur-ws.org/Vol-1857/gamifin17_p7.pdf

Medvedovska D., Skarlupina Y., \& Turchyna, T. (2016). Integrating online educational applications in the classroom. European Humanities Studies: State and Society, 4, 145-156. https://essuir.sumdu.edu.ua/bitstream/123456789/51797/1/Turchyna\%20T.\%2C\%20Medvedovska\%20D.\%2C \%20Skarlupina\%20Y.\%20online.pdf

Miller, M. Game Show Classroom: Comparing Kahoot!, Quizizz, Quizlet Live \& Gimkit. (2016). https://ditchthattextbook.com/2016/04/21/game-show-classroom-comparing-kahoot-quizizz-quizlet-live-and-qui zalize/

Porcaro, P. A., Jackson, D. E., McLaughlin, P. M., \& O'Malley, C. J. (2016). Curriculum design of a flipped classroom to enhance Haematology learning. Journal of Science Education and Technology, 25(3), 345-357. https://doi.org/10.1007/s10956-015-9599-8

Suo, Y. M., \& Suo Y. J., \& Zalika, A. (2018). Implementing Quizizz as game based learning in the Arabic classroom. European Journal of Social Science Education and Research, 12(1), 208-212. https://doi.org/10.26417/ejser.v12i1.p208-212

Watty, K., McKay, J., \& Ngo, L. (2016). Innovators or inhibitors? Accounting faculty resistance to new educational technologies in higher education. Journal of Accounting Education, 36, 1-15. https://doi.org/10.1016/j.jaccedu.2016.03.003

Zichermann, G., \& Cunningham, C. (2011). Gamification by Design: Implementing Game Mechanics in Web and Mobile Apps (1st Ed.). Sebastopol, California: O'Reilly Media. 